\title{
負荷変動をうける電気機械式位置御制系の適応制御†
}

\author{
黒須茂 \\ 與応義愁大学工学部 小金井市前原町 4-5-11 \\ (昭和 45 年 8 月 19 日 受付)
}

\section{Adaptive Control of Electromechanical Position Control \\ System with Load Variation}

\author{
Shigeru Kurosu \\ (Faculty of Engineering, Keio University, Koganei) \\ (Received August 19, 1970)
}

Many practical position control systems have been developed up to now. When the load varies, however, an ordinary feedback control system does not perform satisfactorily.

In this paper, we consider a position control system subject to inertia load variation. An adaptive control of the system with unknown load variation is studied.

1) We determine optimal values of parameters to minimize the performance index with respect to load variation.

2) We design a self-adjusting control system which adjusts its own parameters by measuring the inertia load when the inertia load is constant but unknown before measurement.

3) We design a control system which takes into account the angular acceleration term in addition to PID control and compensates a variation of inertia load through a positive feedback loop when the unknown inertia load varies with time.

The results obtained by digital simulation suggest that the designed control systems are satisfactory for practical use. The simulation also comfirms the requirements to realize an optimal performance.

\section{1. まえがき}

電気機峨式制御装置には，系の外乱とみなさなけれ ばならない負荷変動によるパラメータ変動がある。そ こで, 前もって外乱の形で系に作用する負荷をすみや か認知し自己調整を施しそれによる系の動作への影 響を最小化しなければならない。

本論文では，このような負荷変動に対して適応性を 䚚えた制御系のシンセシスに関卞る研究報告である.

\section{2. 制御系の概要と作動方程式}

この系は，小形のサーボ機構によく使われる電機子 制御直流モータである.

$†$ 第 9 回計測自動制御学会学術講演会 (昭 $45 \cdot 8$ ), 第 14 期 日本自動制御協会学術講演会 (昭 $45 \cdot 5$ ) で発表
Fig. 1 のように電機子電源には直流発電機を用い, その励磁電流を調整するワードレオナード方式である. 最近では，SCR レオナード装置が大容量化し普及し

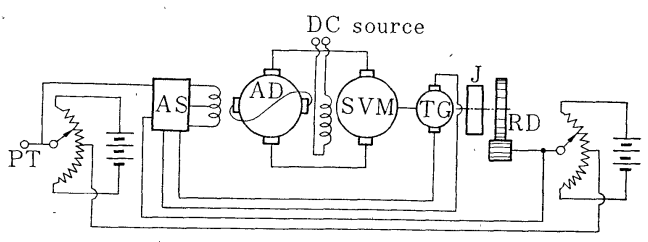

PT : potentiometer, AS : magnetic amplifier; selfsaturating type, AC $200 \mathrm{~V} 50 \mathrm{c} / \mathrm{s}$, output $300 \mathrm{~mA}$, AD : amplidyne; SLY-12 SCK, $4 \mathrm{p} 1 \mathrm{~kW} 1440 \mathrm{rpm}$ $220 \mathrm{~V}$, SVM : DC servo-motor ; MDJ, separatly excited type, $800 \mathrm{~W} 1500 \mathrm{rpm}$, TG: tachometer generator; self excited types, $60 \mathrm{~V}$ (at $1000 \mathrm{rpm}$ ), RD : cyclo reducer ; $1 / 29$ (gear ratio)

Fig. 1 Circuit diagram of the position control system 
てきており, 本方式である磁気増幅器-アンプリダイ ン励磁方式は旧式の感があるが，直流モータを駆動す るワードレオナード方式の負荷特性に特に着目し，モ デルとして本方式を選んだのである.

\section{$2 \cdot 1$ 記 号}

この論文の中で使用されているおもな記号は, 次の と括りである.

$v_{c}, v_{F}$ : AS の基準入力, フィードバック入力電圧 $[\mathrm{V}], K_{c}, K_{F}: \mathrm{AS}$ の基準入力，フィードバック入力 の電流增幅率 $(90,24), R_{c}, R_{F}: \mathrm{AS}$ の基準入力回 路, フィードバック回路の抵抗 $\left(600,28.6 \times 10^{3}\right)[\Omega]$, $N_{G}, N_{c}, N_{F}$ : AS の出力巻線, 基準入力巻線, フィー ドバック巻線の巻数 $(1000,1000,300)$ [turns], $W_{c}, W_{F}$ : AS の特性定数 $\left(1.0 \times 10^{-2}, 0.3 \times 10^{-2}\right)$ [s], $W_{C}=(1 / 2 f)\left(N_{c} / N_{G}\right), \quad W_{F}=(1 / 2 f)\left(N_{F} / N_{G}\right), f=50$ $[\mathrm{Hz}], e_{f}: \mathrm{AS}$ の出力電圧, $\mathrm{AD}$ 制御回路の駆動電圧 $[\mathrm{V}], e_{q}, e_{d}: \mathrm{AD}$ の横軸, 緃軸回路の駆動電圧 $[\mathrm{V}]$, $i_{f}, i_{q}, i_{d}: \mathrm{AD}$ の制御, 横軸, 縦軸回路電流 $[\mathrm{A}]\left(\left|i_{f}\right|\right.$ $\leqq 0.21[\mathrm{~A}]), N_{q q}: \mathrm{AD}$ 横軸電流自体加ら横軸回路飞 誘起された起電力定数 $\left(R_{q}+N_{q q}=7.2\right)[\Omega], N_{d q}$ : $\mathrm{AD}$ 横軸回路の起電力定数 (0.933) $[\mathrm{V} / \mathrm{A}], N_{d d}: \mathrm{AD}$ 縱軸電流自体から綐軸回路に㛬起された起電力定 数 $\left(R_{d}+N_{d d}=2.25\right)[\Omega], N_{q d}: \mathrm{AD}$ 横軸回路による緃 軸回路の起電力定数 $(6.9 \times 10)[\mathrm{V} / \mathrm{A}], N_{f q}: \mathrm{AD}$ 制 御界磁電流に上る横軸回路の起電力定数 (148.2) [V/ $\mathrm{A}], L_{q}, L_{d}: \mathrm{AD}$ 横軸, 縦軸回路のインダクタンス $(0.1265,0.0737)[\mathrm{H}], L_{m}, R_{m}: \mathrm{SVM}$ 電機子回路 のインダクタンス，抵抗 $(0.0103)[H](5.47)$ [ $\Omega]$, $v_{0}: \mathrm{SVM}$ の電機子電圧 $[\mathrm{V}], J: \mathrm{SVM}$ と TG の電 機子と負荷装置の慣性モーメントの和 $(0.240+0.64$ $\left.\times 10^{-2} J_{L}\right)\left[\mathrm{kg} \cdot \mathrm{cm} / \mathrm{rps}^{2}\right], J_{L}$ : 負荷装置の慣性モーメ ント $\left[\mathrm{kg} \cdot \mathrm{cm}^{2}\right], F: \mathrm{SVM}$ と TG の電機子と負荷装 置の摩擦抵抗係数 $(0.2)[\mathrm{kg} \cdot \mathrm{cm} / \mathrm{rps}], \theta_{m}: \mathrm{SVM} の$ 回転角 [回転], $\theta_{c}$ : 回転指示 板 の 回転 角 [回転], $\theta_{r}$ : 目標値 [回転], $T: S V M$ で発生する電磁トルク $[\mathrm{kg} \cdot \mathrm{cm}], K_{m}: \mathrm{SVM}$ の起電力定数 (4.95) [V/rps], $A$ : トルク之起電力との単位変 換係数 $(1.63)[\mathrm{kg}$. $\mathrm{cm} \cdot \mathrm{rps} / \mathrm{watt}], K_{0}: \mathrm{PT}$ のゲイン定数 (3.6) [V/回 転], $K_{T G}$ : TG のゲイン定数 (3.43) [V/rps], $K_{g}$ : $\mathrm{RD}$ の減速比 $(1 / 29), s:$ : ラプラス変換のパラメータ, $t:$ 時間 $[\mathrm{s}]$.

本交中に括ける変数の大文字 $\left(E_{f}, V_{0}\right.$ など) はラプ ラス変換,・は時間微分を示している.

\section{$2 \cdot 2$ 要素の動作方程式 ${ }^{1\rangle}$}

この系の動作方程式を算出するさいに, 厳密にはす べての要素は非線形性を有しているわけであるが，動
作条件の限られた範囲では無視し得る ${ }^{2)}$ 。ここでは操 作部の飽和特性の及考慮する。

磁気增幅器は自己帰還形でリアクトルに施される巻 線には, 電力を供給する出力巻線, 入力の制御磁化力 を与えるための制御巻線, 帰還を行ならためのフィー ドバック巻線がある. 出力はプッシュプル形式でアン プリダインの界磁回路にはいる.

磁気增幅器の出力電圧に対しては,

そのさい,

$$
T_{1} \frac{d e_{f}}{d t}+e_{f}=\frac{R_{f} K_{c}}{R_{c}} v_{c}-\frac{R_{f} K_{F}}{R_{F}} v_{F}
$$

$$
T_{1}=R_{f}\left(\frac{W_{c} K_{c}}{R_{d}}+\frac{W_{F} K_{F}}{R_{F}}\right)
$$

アンプリダインは基本的には，Fig. 2 に示すよう 飞制御回路, 横軸回路和よび縱軸回路より構成され, 制御回路への入力電圧によって生じる横軸回路電流の 電機子反作用を利用して増幅作用を行なわせる.

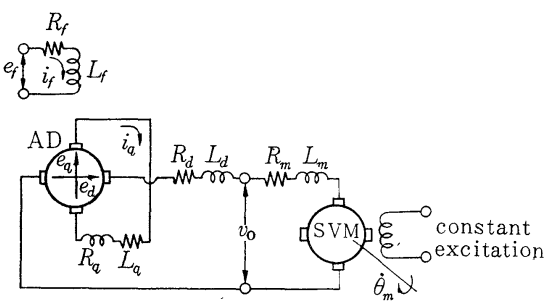

Fig. 2 Schematic diagram of AD \& SVM

制御回路に関しては,

$$
e_{f}=R_{f} i_{f}+L_{f} \frac{d i_{f}}{d t}
$$

横軸回路に関しては,

$e_{q}=N_{f q} i_{f}=\left(R_{q}+N_{q q}\right) i_{q}+L_{q} \frac{d i_{q}}{d t}+N_{d q} i_{d}$

縦軸回路に関しては,

$$
e_{d}=N_{q d} i_{q}=\left(R_{d}+N_{d d}\right) i_{d}+L_{d} \frac{d i_{d}}{d t}+v_{0}
$$

直流サーボモータでは，電機子電圧に対して，

$$
v_{0}=R_{m} i_{d}+L_{m} \frac{d i_{a}}{d t}+K_{m} \frac{d \theta_{m}}{d t}
$$

モータ内で発生する電磁トルクは,

$$
T=A K_{m} i_{d}
$$

また一方では，

$$
T=J \frac{d^{2} \theta_{m}}{d t^{2}}+F \frac{d \theta_{m}}{d t}
$$

速度発電機に対しては開回路電圧,

$$
v_{F}=K_{T G} \frac{d \theta_{m}}{d t}
$$

で与えられ, 磁気增幅器にフィードバックされる。 回転指示板は減速装置を通して結合され， 


$$
\begin{gathered}
\theta_{c}=K_{g} \cdot \theta_{m} \\
\text { ポテンショメータに関して, } \\
v_{c}=K_{0}\left(\theta_{r}-\theta_{c}\right)
\end{gathered}
$$

以上ををとめて，

$e_{f}=z_{1}, \quad i_{f}=z_{2}, \quad i_{q}=z_{3}, \quad i_{d}=z_{4}, \quad \dot{\theta}_{m}=z_{5}, \quad \theta_{c}=z_{6}$, として (1)〜 (10)式を整理すると, この系の数学モデ ルは次の 6 次の連立微分方程式で与えられる.

$$
\begin{aligned}
& \dot{z}_{1}=a_{1} z_{1}+a_{2} v_{c}+a_{3} v_{F} \\
& \dot{z}_{2}=b_{1} z_{2}+b_{2} z_{1} \quad\left|z_{2}\right| \leqq 0.21 \\
& \dot{z}_{3}=c_{1} z_{3}+c_{2} z_{2}+c_{3} z_{4} \\
& \dot{z}_{4}=d_{1} z_{4}+d_{2} z_{3}+d_{3} z_{5} \\
& \dot{z}_{5}=e_{1} z_{5}+e_{2} z_{4} \\
& \dot{z}_{6}=K_{g} z_{5} \\
& v_{F}=K_{T G} z_{5}, \quad v_{c}=K_{0}\left(\theta_{r}-z_{6}\right)
\end{aligned}
$$

そのさい, $a_{1}=-1 / T_{1}, \quad a_{2}=R_{f} K_{c} / T_{1} R_{c}, \quad a_{3}=R_{f} K_{F} /$ $T_{1} R_{F}, \quad b_{1}=-R_{f} / L_{f}, \quad b_{2}=1 / L_{f}, \quad c_{1}=-\left(R_{q}+N_{q q}\right) / L_{q}$, $c_{2}=N_{f q} / L_{q}, \quad c_{3}=-N_{d q} / L_{q}, \quad d_{1}=-\left(R_{d}+N_{d d}+R_{m}\right) /$ $\left(L_{d}+L_{m}\right), d_{2}=N_{d q} /\left(L_{d}+L_{m}\right), d_{3}=-K_{m} /\left(L_{d}+L_{m}\right)$, $e_{1}=-F / J, e_{2}=A K_{m} / J$.

また（1）～(10) 式をラプラス変換すると Fig. 3 に示すブロック線図で表わすことができる、ステップ 入力に対する過渡応答をディジタル計算機を使って求 め実測した過渡応答と比較する。

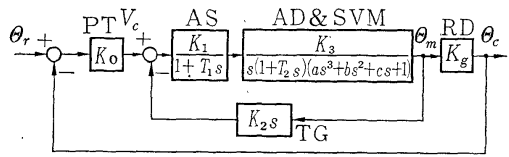

$k_{0}=3.6, \quad k_{1}=17.1, \quad k_{2}=0.02065, \quad k_{g}=1 / 29$,

$T_{1}=0.171, \quad T_{2}=0.00105, k_{3}=2.32, a=9.42 \times 10^{-6}$ $+2.51 \times 10^{-7} J_{L}, \quad b=1.47 \times 10^{-3}+3.88 \times 10^{-5} J_{L}$, $c=0.110+2.46 \times 10^{-3} J_{L}$

Fig. 3 Blook diagram of the position control system

まず，手始めに目標值 $60^{\circ}\left(\theta_{r}=1 / b\right)$ に対し慣性負 荷の一定の場合を Fig. 4 に示してある.

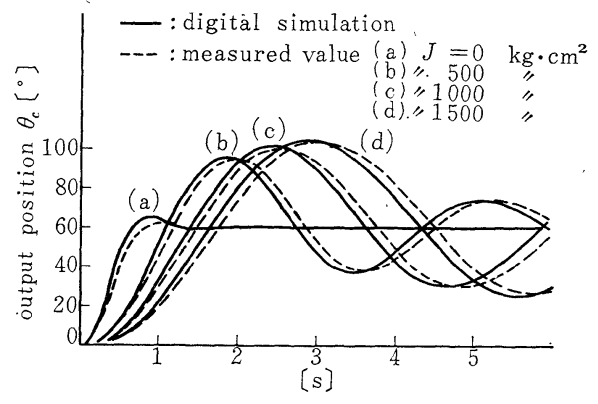

Fig. 4 Response of the ordinary feedback system to step change of command position
この結果， $T_{L}$ の増大とともに制御成績が悪くなり 実測した過渡応答から(11)式がこの系の数学的モデル として妥当であることが解かる.

次に, 慣性負荷が時間とともに変動する場合の結果 を Fig. 5 に示してある. 質量が時間的に変化する例 は制御系の問題に叔いてまれでなく，たとえば鋼板の ような製品を巻き取ったり巻き戻したりしている巻胴 の質量は連続的に変化する. SVM を駆動するのに必 要なトルクは次のようになる.

$$
T=\frac{d}{d t}\left(J \frac{d \theta_{m}}{d t}\right)+F \frac{d \theta_{m}}{d t}=J \frac{d^{2} \theta_{m}}{d t}+\left(F+\frac{d J}{d t}\right) \frac{d \theta_{m}}{d t}
$$

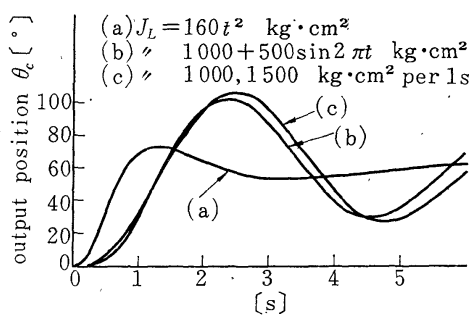

Fig. 5 Response of the ordinary feedback control system to step change of command position

\section{3. パラメータの最適調整}

制御量だけを注視の的とする制御論では，制御パラ メータ（ゲイン，積分時間など）または補償回路の定 数を応答の恰好がよくなるように選定する。しかし， 単にゲインを上げるといら表現を用いているが，実際 問題として新しい増幅器でも用意しない限り位相をか えないでゲインを上げることは不可能である。という のは, 系の構成要素のパラメータを変化させた場合互 いに相互干渉して位相も変わってしまら。そこであら ためて周波数応答を求めることとなる。これは非常に 根気と時間を要する3).これでたよりないとすると， 実際上意味があってしかも計算可能な評価関数につい てこれを最小にするようなパラメータの集合を決定す る方法をとることとなる。

\section{$3 \cdot 1$ パラメー夕最適化問題の定式化}

この系に和けるパラメータの内，いくつかのものは 調整可能であり，制御方式をそのままにしてこれらの パラメータの選定いかんによって制御成績を上げるこ とが期待できる.

評価関数 $f$ とて 2 乗偏差積分 (ISE) をとり指定 する拘束条件のもとに $f$ 極值にするパラメータの集 合を決定する問題を定式化すると次のようになる.

目標值 $60^{\circ}\left(\theta_{r}=1 / 6\right)$ として状態方程式(11) 式と, 
拘束条件 $\quad 200 \leqq R_{c} \leqq 2850 \quad[\Omega]$

$10 \times 10^{3} \leqq R_{F} \leqq 40 \times 10^{3}[\Omega]$

$15 \leqq R_{f} \leqq 115 \quad[\Omega]$

$4.56 \leqq K_{m} \leqq 11.3 \quad[\mathrm{~V} / \mathrm{rps}]$

$3.13 \leqq K_{0} \leqq 7.55 \quad[\mathrm{~V} /$ 回転 $]$

のもとに, 評価関数

$$
f=\int_{0}^{T} e^{2} d t, \text { ただし }, e=\theta_{r}-z_{6}, T=5 \mathrm{~s}
$$

を最小にするよらな最適パラメータ $\left(R_{c}^{\circ}, R_{F}{ }^{\circ}, R_{f}{ }^{\circ}\right.$, $\left.K_{m}{ }^{\circ} ， K_{0}{ }^{\circ}\right)$ を見出すこと.

系が複雑で操作部の飽和特性など非線形性を考虑に 入れた評価関数の算出には, 定常状態とみなし得るま での積分值をとれば $f$ につての近似值を得ることが できる. Fig. 4 から $T=5 \mathrm{~s}$ を決定した.

\section{$3 \cdot 2$ 最適化問題の解法}

評価関数の一階の導関数のみを利用して 2 次収束性 を有する手法には Fletcher-Powell, Fletcher-Reeves の方法がある $\left.{ }^{4)}, 5\right)$. 後者は前者と比較して計算量 特よび記憶容量も少ないので現在連続プロセスなどに 使用されている6)。ここでは本方法を採用する.

上記の手法は調整する変数間に制約がない場合であ り，拘束条件のついた最適化問題には種々の手法が開 発されている7)。乙かし，ここで取扱う最適化問題の 拘束条件は調整パラメータの範囲を示す単純な制約式 と考光ることができる，そこで，拘束条件なしの手法 を微小移動が制約を侵害せず評価関数を改良するよう な方向に修正する。すなわち, 探索べクトル $\boldsymbol{x}$ の成分 $x_{i}$ が境界 $x_{i}{ }^{*}$ に達したとき， $x_{i}$ は $x_{i}{ }^{*}$ に固定し他 の成分についてのみ修正を行なら。沁, 最小化す べき評価関数の形状によっては領域内でいくつかの局 部的最小值をもつことが考兄られるので Fig. 7 に示 すようにいくつかの初期点について探索する必要があ る.

\section{$3 \cdot 3$ 計算結果}

探索すべきべクトルの成分 $x_{1}, x_{2}, \cdots, x_{n}$ は，単位 変化によって評価関数が $1 \%$ 変化し得るように正規化 した. すなわち， $x_{1}=R_{c} / 40, x_{2}=R_{F} / 29.3 \times 10^{3}, x_{3}=$ $R_{f} / 4.4, x_{4}=K_{m} / 0.854, x_{5}=K_{0} / 0.14$.

まず，種々の $J_{L}$ 飞対して任意の初期点から出発し その収束状況を繰返し計算回数に対して示すと Fig. 6 のようになる。

その結果, $J_{L}=500 \mathrm{~kg} \cdot \mathrm{cm}^{2}$ までは制御成績を向上 させることができたのであるが, $J_{L}=1000 \mathrm{~kg} \cdot \mathrm{cm}^{2}$ 以 上になるとこの制御方式からで御成績の向上は望 めないので 4 章で述べる制御方式が必要となる.

また， $J_{L}=0 \mathrm{~kg} \cdot \mathrm{cm}^{2}$ の場合に計算回数が多いのは

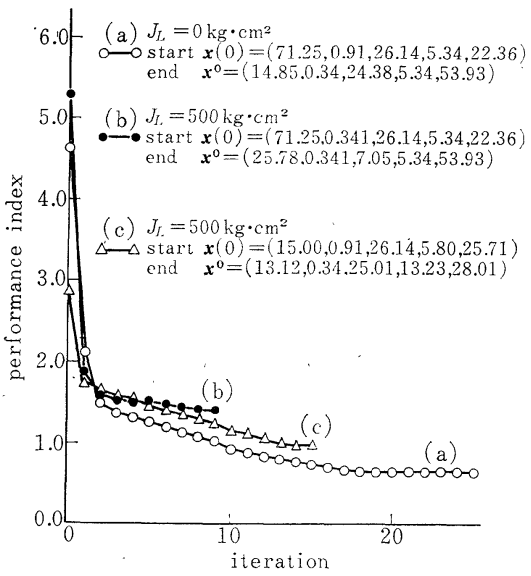

Fig. 6 Decrease in the performance index パラメータに存在領域を課したからであり，fが比較 的滑らかななべ底であれば Fig. 7 に示すように $x_{1}$

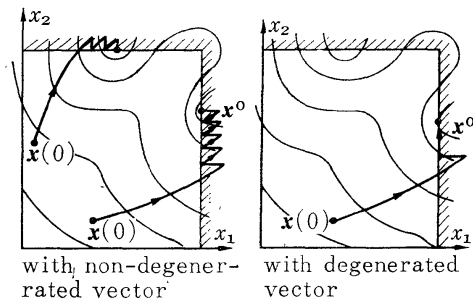

Fig. 7 Optimum gradient trajectory

が境界に達したら $x_{1}=x_{1}{ }^{\circ}$ に固定してその成分を探索 ベクトル $\boldsymbol{x}$ の成分から削除して 1 次元縮退したベクト ルについて探索を繰返す方法が計算時間を短くする.

次に，得られたパラメータの最適值を用いた場合の 過渡応答を示すと Fig. 8 のようとなる。

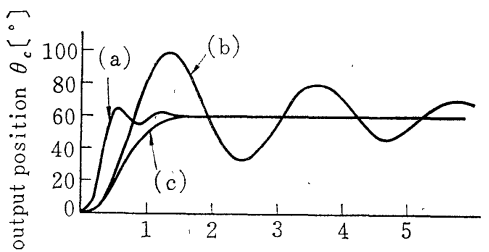

[s]

(a) $R_{c}=594, \quad R_{F}=10 \times 10^{3}, \quad R_{f}=107$, $K_{m}=4.56, \quad K_{0}=7.55$

(b) $R_{c}=1020, R_{F}=10 \times 10^{3}, R_{f}=31$, $K_{m}=4.56, K_{0}=7.55$

(c) $R_{c}=525, \quad R_{F}=10 \times 10^{3}, \quad R_{f}=110$, $K_{m}=11.3, \quad K_{0}=3.92$

Fig. 8 Step response of the optimum parameter system

以上の計算は TOSBAC 3400 で計算した結果であ るが，JLがそらひんぱん変わらないときには DDC で実現できる。 


\section{4. パラメータ自己調整による適 応制御系の構成}

この系に扔いて外乱（負荷慣性）がはいると（6)式 のように系の運動を記述する微分方程式の係数が変化 する．そこで，未知であるが一定の慣性負荷を駆動す るさいに，制御対象の特性变化を検出して系のパラメ 一タを自己調整する適応制御系を考光る。

$4 \cdot 1$ パラメータ調整のためのアルゴリズム

(2)〜 (6) 式をラプラス変換し, AD の出力電圧を 導くと,

$$
V_{0}=H E_{f}-Z_{0} I_{d}
$$

ここで,

$$
\begin{gathered}
H=\frac{N_{f q} N_{q d} / R_{f}\left(R_{q}+\dot{N}_{q q}\right)}{\left(T_{f} s+1\right)\left(T_{q} s+1\right)} \\
Z_{0}=R_{d}+N_{d d}+L_{d} s+\frac{N_{d q} N_{q d} /\left(R_{q}+N_{q q}\right)}{T_{q} s+1}, \\
T_{f}=L_{f} / R_{f}, \quad T_{q}=L_{q} /\left(R_{q}+N_{q q}\right)
\end{gathered}
$$

$S V M$ は開回路電圧 $E_{0}$ と出力インピーダンス $Z_{0}$ をもつ発電機に接続されていると考兄て伝達関数を求 めると，

$$
\frac{\Theta_{m}(s)}{E_{0}(s)}=\frac{\frac{A K_{m}}{F}}{s\left\{\left(1+\frac{J}{F} s\right)\left(Z_{0} R_{m}+L_{m} s\right)+\frac{A K_{m}^{2}}{F}\right\}}
$$

となる.ここで $E_{0}=H E_{f}$ である.

(14)式に招いて制動係数 $F$ を慣性負荷飞比例して可 変すれば SVM の時定数は一定となる. しかし, 制動 係数のみ可变汇にしてる分母の末項 (2 次系の復元力 の項）が減少し，これを補償するために $K_{m}$ を可変 にする必要がある。

以上のことを達成したとき系の特性方程式を不変に することができるが，パラメータ調整により各項で消 費されるトルクを補償するために供給電圧を增加する。 そのためにPT のゲインを可変にする.

以上の数式上の演算機構のアルゴリズムをまとめる そ Table 1 のようになる.

パラメータ自己調整機構で $K_{m}, K_{0}$ は界磁電流特よ

Table 1 Argorithm of adjusting parameters

\begin{tabular}{c|c}
\hline with no-load & with load \\
\hline$J_{0}$ & $J_{L}$ \\
\hline$F_{0}$ & $F_{L}=\left(J_{L} / J_{0}\right) F_{0}$ \\
\hline$K_{m 0}$ & $K_{m L}=K_{m 0} \sqrt{J_{L} / J_{0}}$ \\
\hline$K_{00}$ & $K_{0 L}=K_{00} \sqrt{J_{L} / J_{0}}$ \\
\hline
\end{tabular}

(0: no load, $L:$ load)
び電源電圧の変化によって可変にし得るが, 制動俰数 $F$ は“アラゴの円板”の逆の原理を利用した渦電流に よる電気的制動によって実現し得る.

\section{2 負荷の認知亡系の構成}

理論的解析により伝達関数の形はすでにわかってい るが，その一部（負荷慣性を含む項）が未知であるの で同定問題としては特殊な場合である.

$\mathrm{AS}, \mathrm{AD}$ の時間遅孔を無視するとこの系は 2 次系で 表現し得る.

閉ループ伝達関数,

$$
\frac{\Theta_{c}}{\Theta_{r}}=\frac{\omega_{n}^{2}}{s^{2}+2 \zeta \omega_{n} s+\omega_{n}^{2}}
$$

ここで,

$$
\begin{aligned}
\omega_{n} & =\left(\frac{A K_{m} K_{1} K_{0} K_{g}}{J R_{a}}\right)^{1 / 2} \\
\zeta & =\frac{F R_{a}+A K_{m}^{2}+A K_{m} K_{1} K_{2}}{2\left(J R_{a} A K_{m} K_{1} K_{0} K_{g}\right)^{1 / 2}} \\
R_{d} & =R_{d}+N_{d d}+R_{m}+N_{d q} N_{q d} /\left(R_{q}+N_{q q}\right) \\
K_{1} & =K_{c} N_{f q} N_{q d} / R_{c}\left(R_{q}+N_{q q}\right) \\
K_{2} & =K_{F} R_{c} K_{T G} /\left(K_{c} R_{F}\right)
\end{aligned}
$$

(15)式から振動根を含む 2 次系のステップ応答は,

$$
\frac{\theta_{c}}{\theta_{r}}=1+\frac{e^{-\zeta \omega_{n} t}}{\sqrt{1-\zeta^{2}}} \sin \left[\omega_{n} \sqrt{1-\zeta^{2}} t-\tan ^{-1} \frac{\sqrt{1-\zeta^{2}}}{-\zeta}\right]
$$

$t=0$ の近傍でテーラ級数で展開し, $t$ の 2 次以上 の項を省略すると，

$$
\frac{\theta_{c}}{\theta_{r}}=\zeta \omega_{n} t=\frac{K}{J_{L}} t
$$

ここで,

$$
K=\frac{F R_{a}+A K_{m}^{2}+A K_{m} K_{1} K_{2}}{2 R_{a}} \text { (定数) }
$$

次に実際の系の応答を 0.6 秒までプロットしたもの が Fig. 9 である.

Fig. 9 から $t=0.4 \mathrm{~s}$ に晾㤃る応答と $J_{L}$ の関係式 は近似的に次のように書ける。

$$
\theta_{c}=18 /\left(J_{L}\right)^{0.92}
$$

これを書き換えると，

$$
J_{L}=\left(18 / \theta_{c}\right)^{1.087}
$$

である、ただし， $\theta_{c}$ ：応答 $\left[^{\circ}\right], J_{L}$ : 負荷 $[\mathrm{kg} \cdot \mathrm{cm} /$ $\left.\mathrm{rps}^{2}\right]$.

したがってこの系の応答 $\theta_{c}$ を指定時刻 $t=0.4 \mathrm{~s}$ に拈ける PT の偏差電圧から検出することによって $J_{L}$ を認知することができる.

以上をとめて未知の負荷慣性が加わったときでも, 無負荷時に近似した応答を示すようにパラメータを調 整する系をブロック線図で示すと Fig. 10 のように なる。 


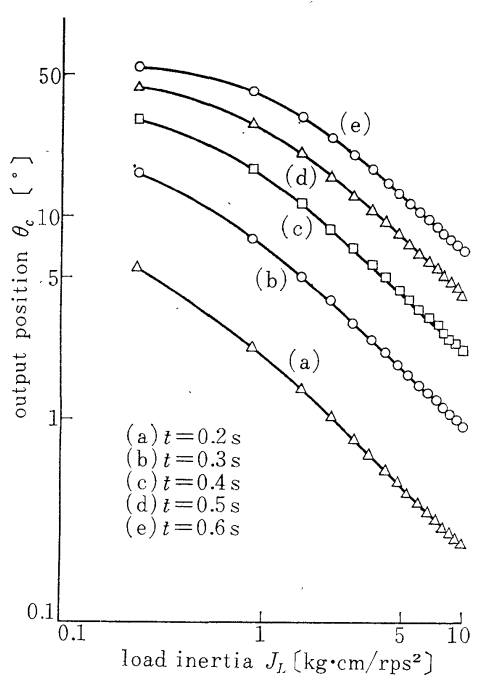

Fig. 9 Relation of load vs outpict

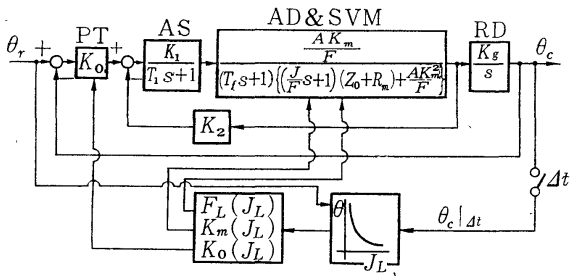

Fig. 10 Block diagram of the self-adjusting system

種々の負荷慣性に対する応答をディジタル計算機を 使って求めると Fig. 11 のようになる.

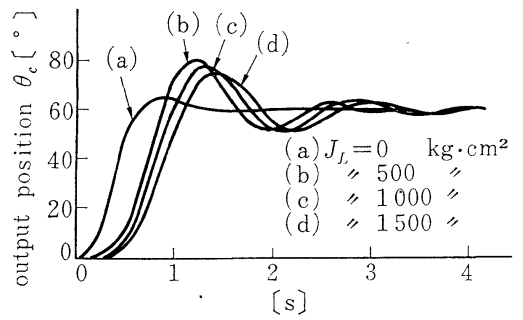

Fig. 11 Step response

\section{5. 角加速度を考慮した適応制御系の構成}

次に，未知の慣性負荷が時間の関数として変動する さいに時々刻々時間の関数として負荷を認知し, 負荷 に応じたアクションを考虑する問題にはいる。

角加速度の検出が可能である場合には, 系の数学的 モデルがわかっているので逆算により慣性負荷を認知 でき，更にその情報をるとに慣性負荷の変動を打ち消 すように操作量を加えることができればよい．

\section{$5 \cdot 1$ 正フィードバックによる補償量の算出}

(5)，(11)式から次の式が導かれる.

$$
J \frac{d^{2} \theta_{m}}{d t^{2}}+\left(F_{0}+\frac{d J}{d t}\right) \frac{d \theta_{m}}{d t}=A K_{m} i_{d}
$$

ここで, $J(t)=J_{0}+\alpha J_{L}\left(J_{0}\right.$ ：無負荷時の慣性）

(20)式の右辺（入力側）である SVM の駆動トルク として $\mathrm{AD}$ 縦軸電流 $i_{d}$ に次式で示される補正量 $T_{c}$ を加学る。

$$
T^{\prime}=T+T_{c}=A K_{m} i_{d}+\alpha J_{L} \frac{d^{2} \theta_{m}}{d t^{2}}+\frac{d J_{L}}{d t} \frac{d \theta_{m}}{d t}
$$

(21)式を(20)式に代入すると次式を得る.

$$
J_{0} \frac{d^{2} \theta_{m}}{d t^{2}}+F_{0} \frac{d \theta_{m}}{d t}=A K_{m} i_{d}
$$

この式は無負荷時に和ける動作方程式であり，(21) 式に括ける $\ddot{\theta}_{m}, \dot{\theta}_{m}, J_{L}$ なる計測值に基づいて系の応 答を改善することができる.

\section{$5 \cdot 2$ 角加速度の検出方法}

直線運動に拈ける加速度計の原理 ${ }^{9)}$ を回転運動に適 用すれば，Fig. 12 に示すような角加速度計を構成す

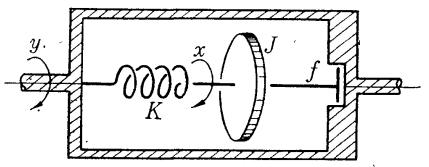

Fig. 12 Angular accelerometer

ることができる．ここで， $f$ : 回転部の粘性 係数,

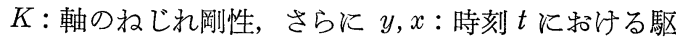
動軸怙よび慣性軸の回転角，回転角の差を $l(=y-x)$ とすると, 慣性 $J$ の運動方程式は,

$$
J \ddot{y}=J \ddot{l}+K l+f i
$$

となる.これは 2 次系の共振回路である.

ここでの角加速度計は，定常状態に初めて有効な情 報を与光るものであるから，過渡現象がすみやかに消 隇するものであって欲しい.したがって $\omega_{n}=(K / J)^{1 / 2}$, $\zeta=f / 2(K J)^{1 / 2}$ の選定が重要となる.

2 次系のサーボ機構のシンセシスでは経験值として $\zeta=0.6 \sim 0.8$ が採用され，また $\omega_{n} t=10$ に到達する とほとんど定常状態に達しているとみなし得る。

角加速度計のもつ過渡現象が $0.1 \mathrm{~s}$ 以内に消減する ことを目安として $\omega_{n} \geqq 100$ が得られる.

\section{3 負荷の認知と系の構成}

負荷慣性を角加速度 $\ddot{\theta}_{m}$, 角速度 $\dot{\theta}_{m}$ の測定からど のようにして認知するかを考觉る。

Fig. 5 に示したよらに， $J_{L}$ がステップ状に変動す るときは $F$ は不変であるから，次のように負荷は代数 


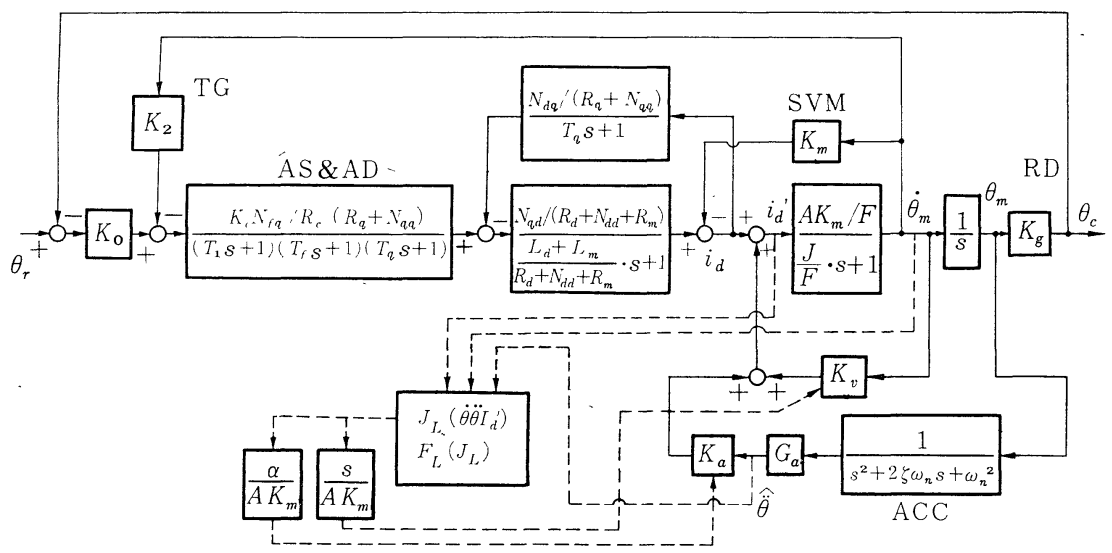

Fig. 13 Block diagram of the overall control system with angular accelerometer

方程式で与えられる.

$$
J=\frac{1}{\hat{\tilde{\theta}}_{m}}\left(A K_{m} \hat{i}_{d}-F \hat{\theta}_{m}\right)
$$

ここで, ^は測定值を示す.

$J_{L}$ が時間の関数の場合には, $J, F$ は次の連立微分 方程式で示される.

$$
\left.\begin{array}{l}
J \hat{\ddot{\theta}}_{m}+F \hat{\dot{\theta}}_{m}=A K_{m} \hat{i}_{d} \\
F=F_{0}+d J / d t
\end{array}\right\}
$$

(25)式から，負荷慣性は次の式の解で与兄られる.

$$
\frac{d J}{d t}=-\frac{\hat{\ddot{\theta}}_{m}}{\hat{\hat{\theta}}_{m}} J+\frac{A K_{m} \hat{i}_{d}}{\hat{\hat{\theta}}_{m}}-F_{0}
$$

$F$ は(26)式を(25)式の第 2 式に代入して得られる.

以上の式に各時刻ごとにはいる情報 $\hat{\ddot{\theta}}_{m}, \hat{\theta}_{m}, \hat{i}_{d}$ を代 入して逐次近似解を得るわけである。本論文に掠ける シミュレーションでは (26) 式を Runge-Kutta Gill 法による数值計算法を用いて処理した.

以上の考察をまとめて, 角加速度の検出特よび負荷 慣性の変動を補償する機構を含めた適応制御系のブロ ック線図を示すと Fig. 13 のようとなる.

Fig. 13 で角加速度検出機構のゲイン定数 $G_{a}$ は,

$$
G_{a}=\omega_{n}^{2}
$$

で与兄られるが，制御系に組込えださいに RouthHurwitz の安定判別法より $G_{a}$ の值を横討すると次 式を得る.

$$
G_{a} \leqq \omega_{n}^{2}
$$

しかし, $G_{a}$ の值が $\omega_{n}^{2}$ の場合は不安定領域に近い ので補正係数

\section{4 結 果}

角加速度計 (1) $\omega_{n}=100, \quad \zeta=0.6$ （2） $\omega_{n}=200$, $\zeta=0.6$ を用いて, 種々の $\xi$ 対してディジタル計算 機を使って求めたシミレーション結果を Fig. 14 亿示

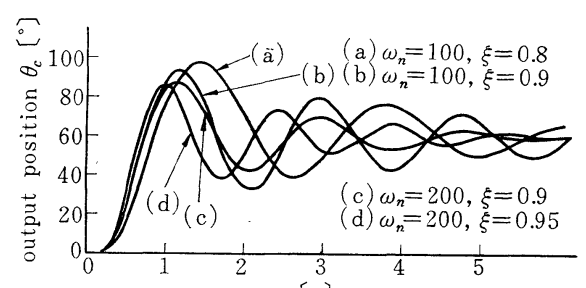

[s]

$J_{L}=1000+500 \sin 2 \pi t\left[\mathrm{~kg} \cdot \mathrm{cm}^{2}\right]$

(a) step response of the system with sinusoidal load variation

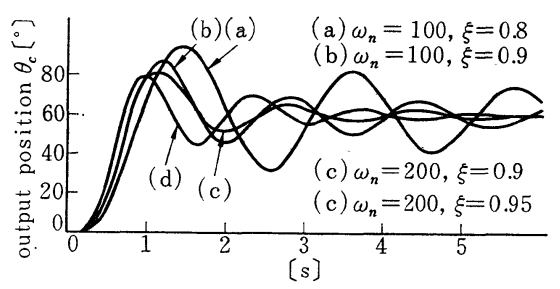

$J_{L}=1000,1500 \mathrm{~kg} \cdot \mathrm{cm}^{2}$ per $1 \mathrm{~s}$

(b) step response of the system with step wise load variation

Fig. 14

した.

4 章で検討した $J_{L}$ が一定の場合についても本制御 方式を用いて，同様に制御成績が改良されることを検 証した ${ }^{3)}$.

\section{6. むす び}

負荷慣性の変動は制御系の動的な応答にのみ影響を 及ぼすので定常特性を重要視するプロセスでは問題に することはないが, 動的挙動を重要視する多くのプロ セスではその変動のプロセス応答への影響を少なくす ることが必要である.

本論文では, この点に着目して負荷変動を.ちと制 
御系の適応制御方式として種々検討したわけである.

それらをディジタル計算機によるシミュレーションよ り従来のフィードバック方式より制御成績が改善され ることを検証した.

得られた結果は原理的にほ注満足すべきものである が，実際への応用には角加速度および演算機構に対す る測定誤差捄よびノイズの影響などの考慮が必要とな ろう。

終わ.りに当たって本研究の方向づけに関し終始ご指 導をいただいた冨沢 豁教授ならびに志水清孝講師に 深く感謝の意を表します。

\section{参 考 文 献}

1) J.E. Gibson \& F. B. Tuteur : Control System Components ; Mcgraw-Hill (1958)

2）仁田工吉・沖津 泰 : 非線形性を考虑した直流電動機
の動特性, 制御工学, 9-2, 28/38 (1965)

3）慶応大学院 44 年度修士論文：負荷変動を5 汀る電気 式制御系の適応制御

4) R. Fletcher \& M. J.D. Powell : Rapidly Convergent Descent Method for Minimization, The Computer Journal, 6-2, 163/168 (1964)

5) R. Fletcher \& C.M. Reeves : Function Minimization by Conjugate Gradients, The Computer Journal, 7-2, 149/154 (1964)

6）高松武一郎・佐山隼敏・大井紘：2 次収束グラジェン ト法による抽出プロセスの最適設計，制御工学， 13-5, 313/321 (1969)

7） 志水清孝：システムの制約条件付最適化手法，計測と 制御，9-7，519/530 (1970)

8) L.S. Lasdon \& A.D. Waren : Mathematical Programming for Optimal Design, Electro-Technology, 55/70 (1967)

9) D.P.Eckman : Industrial Instrumentation, John Wiley \& Sons, 210/214 (1958)

\section{論文集論文に対する討論の募集}

$\diamond$ 会員相互の知識の交換のため，論文集には寄書欄を設けてあります。

$\diamond$ 新しい着想や学術上の所見はもとより，実験結果または論文集の論文に対する質問・討 論・意見などなるべく短くまとめて（0.5〜2 ページ以内）御投稿ください。

$\diamond 9$ 月 25 日までの投稿は次号に掲載されるよう努力します. 